\title{
Arc Sendromlu Yenidoğan Olgusu
}

\author{
A Newborn Case of Arc Syndrome
}

Kanuni Sultan Süleyman Eğitim ve Araştırma Hastanesi, Çocuk Gastroenteroloji, Hepatoloji ve Beslenme Bilim Dalı, İstanbul, Türkiye

Kanuni Sultan Süleyman Eğitim ve Araştırma Hastanesi, Çocuk Sağlığı ve Hastalıkları Anabilim Dalı, İstanbul, Türkiye

Kanuni Sultan Süleyman Eğitim ve Araștırma Hastanesi, Çocuk Nefroloji Bilim Dal, İstanbul, Türkiye

Kanuni Sultan Süleyman Eğitim ve

Araştırma Hastanesi, Radyoloji Anabilim Dalı, İstanbul, Türkiye

Kanuni Sultan Süleyman Eğitim ve

Araştırma Hastanesi, Ortopedi Bilim Dalı, İstanbul, Türkiye

\section{Correspondence:}

Özlem KALAYCIK ŞENGÜL,

Kanuni Sultan Süleyman Eğitim ve Araştırma Hastanesi, Çocuk

Gastroenteroloji,

Hepatoloji ve Beslenme Bilim Dalı, İstanbul, Türkiye

e-mail: kalaycikoz@yahoo.com

\section{${ }^{1}$ Özlem Kalaycık Şengül, ${ }^{2}$ Didem Kalaycı Atmaca, ${ }^{3}$ Rumeysa Yasemin Çiçek, ${ }^{4}$ Sümeyra Doğan, ${ }^{5}$ Erdal Eren, ${ }^{1}$ Günsel Kutluk \\ (i)} Özet

Artrogripozis, renal disfonksiyon ve kolestaz (ARC) sendromu artrogripozis, renal tübüler disfonksiyon ve düşük veya normal gama glutamil transferaz aktivitesine sahip neonatal kolestaz ile karakterize nadir görülen otozomal resesif multisistemik bir hastalıktır. Mortalitesi yüksek olan bu hastalığın tanısı VPS33B ve VIPAR sekanslama analizleri ile konmaktadır. Yoğun tedaviye rağmen hastaların çoğu sıvı kaybı, beslenme problemi, kanama ve tekrarlayan enfeksiyonlar nedeniyle yaşamın ilk yılında kaybedilir. Yenidoğan döneminde kolestaz ile başvuran olgularda, klinisyenin ayırıcı tanıda bu sendromu akılda bulundurması, ailenin tekrar çocuk sahibi olması durumunda genetik danışmanlık alabilmesi açısından önem arz etmektedir. Bu yazıda, yenidoğan döneminde kolestaz ile başvuran ARC sendrom tanılı bir olgu sunulmaktadır.
\end{abstract}

Anahtar Kelimeler: Artrogripozis renal disfonksiyon ve kolestaz sendromu; yenidoğan; malnütrisyon

\section{Abstract}

Arthrogryposis, renal dysfunction and cholestasis syndrome is a rarely seen autosomal recessive multisystemic disease, which is characterized by arthrogryposis, renal tubular dysfunction and neonatal cholestasis with low gamma-glutamyl transferase activity. It has a high mortality rate and is diagnosed by VPS33B and VIPAR sequence analysis. Most of the patients die in the first year of life due to dehydration, malnutrition, hemorrhage and recurrent infections. Regarding the differential diagnosis of newborn cholestasis, clinicians should keep this disorder in mind in order to facilitate a genetic counseling before the following conception. In this case, a patient with newborn cholestasis who is diagnosed with ARC syndrome is being discussed.

Keywords: Arthrogryposis renal dysfunction and cholestasis syndrome; newborn; malnutrition 


\section{Giriş}

Artrogripozis, renal disfonksiyon ve kolestaz (ARC) sendromu, otozomal resesif geçişli multisistemik tutulumlu nadir görülen bir hastalıktır. Konjenital eklem kontraktürleri, renal tübüler asidoz ve neonatal kolestatik sarılık, bu sendromun klasik kliniğini oluşturmaktadır. İktiyoz ( $\% 50)$, trombosit anomalisi ( $\% 25)$, korpus kallozum agenezisi $(>\% \quad 20), \quad$ konjenital kardiyovasküler anormallikler $(\sim \% 10)$, nefrojenik diabetes insipidus, hipotiroidizm, tekrarlayan sepsis, sağırlık ve ciddi gelişme gerilikleri sendroma eșlik edebilir1. Mortalitesi yüksek olan bu hastalığa, VPS33B veya VIPAR genlerindeki homozigot veya bileşik heterozigot mutasyonlar neden olur2. Hastalığın tanıs1, ailenin tekrar çocuk sahibi olması durumunda, genetik danışmanlık alabilmesi açısından önem arz etmektedir. Bu yazıda, yenidoğan döneminde kolestaz ile başvuran ARC sendrom tanılı bir olgu sunulmaktadır.

\section{Olgu Bildirisi}

Hasta yakınından yazılı onam formu alınmıştır.

Otuz dört günlük erkek bebek sarılık nedeniyle hastanemize başvurdu. Öyküsünden bir haftalıkken dış merkez yenidoğan yoğun bakım servisinde sendromik görünüm ve sarılık nedeniyle yatırıldığı ve kolestaz saptanması üzerine hastanemize sevk edildiği öğrenildi. 37. gestasyonel haftada 2500 gram doğan bebek, sağlıklı, akrabalık hikayesi olmayan Suriyeli bir ailenin ilk çocuğuydu. Soy geçmiş sorgulandığında ailede bilinen bir hastalı ve bebeklik döneminde ölüm öyküsünün olmadığı öğrenildi. Fizik muayenede; vital bulguları stabil olan hastada dismorfik özellikler [düşük kulak, gaga ağızlı burun, migrognati, kifoz, üst ekstremitede fleksiyon kontraktürü, bilateral bileklerde radial deviasyon, mediale doğru üst üste binmiş ve ulnar deviye parmaklar, bilateral alt ekstremitede abdüksiyon ve ekstensiyon kısıtlılığı, ekinovarus ve yumru ayak deformitesi], ikter, kuru cilt, kaşeksi, kalpte üfürüm, hepatomegali (kot altı $2 \mathrm{~cm}$ ), inguinal herni (sağda) saptandı (Resim 1). Vücut ağırlığı: 2300 gram $(<3$ p), boy: $48 \mathrm{~cm}(3 \mathrm{p})$ ve baş çevresi: $32 \mathrm{~cm}(<3$ p) ölçüldü. Laboratuvar incelemelerinde, hemoglobin 9 gr/dl, lökosit sayıs1 $26550 / \mathrm{mm} 3$ ve trombosit sayıs $645000 / \mathrm{mm} 3$ idi. Periferik yaymasında atipik hücre saptanmadı ve trombosit morfolojisi normal görüldü. Biyokimyasal incelemelerinde: Alanin aminotransferaz (ALT) 48 (normal: 0-56 IU/L); aspartat aminotransferaz (AST) 56 (normal: 0-84 IU/L); alkalen fosfataz (ALP) 828 (normal: 122-469 IU/L); gama-glutamil transferaz (GGT) 35 (normal: 0-61 IU/L); total bilirubin: 15,2 (normal: $0-1,2 \mathrm{mg} / \mathrm{dl}$ ); direkt bilirubin $13,2 \mathrm{mg} / \mathrm{dl}$; total protein 5,4 (normal: 4,4-7,6 gr/dl); albümin 3,5 (normal: 3,8-5,4 gr/dl); kan üre azotu (BUN) 12,62 (normal: 8-24 $\mathrm{mg} / \mathrm{dl}$ ); kreatin 0,34 (normal: 0,17-0,42 mg/dl) idi. Böbrek fonksiyon testleri normal olan hastanın hipernatremi (Sodyum:148 mmol/L) ve hiperkloremisi (Klor:122 $\mathrm{mmol} / \mathrm{L}$ ) mevcuttu. Venöz kan gazında normal anyon açıklı metabolik asidozu ve tam idrar analizinde glukozüri, generalize aminoasidüri, tübüler proteinüri, fosfatüri saptandı ve bu bulgular Fanconi Sendromu ile uyumlu bulundu. Ultrasonografide her iki böbrek boyutları normal olmakla birlikte parankim ekojenitesi grade 1 artmış görüldü. 


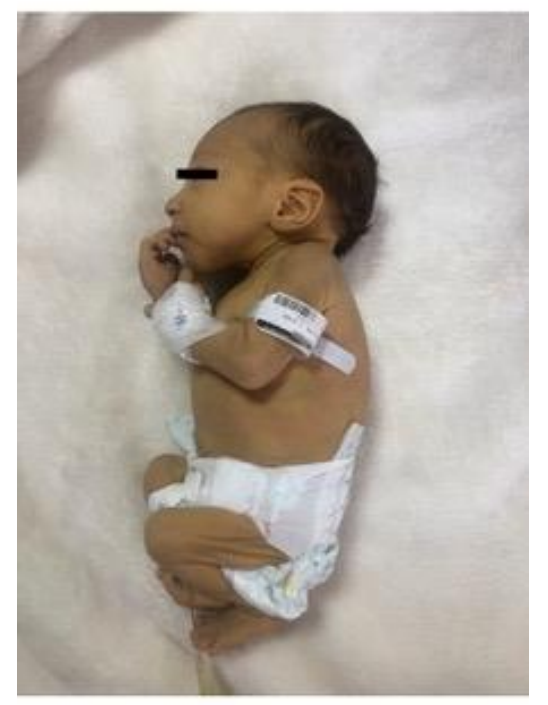

Resim 1. Artrogripozis, renal disfonksiyon ve kolestaz (ARC) sendromu olan 34 günlük erkek bebek. Dismorfik özellikler: migrognati, kifoz, üst ekstremitede fleksiyon kontraktürü, bilateral alt ekstremitede abdüksiyon ve ekstensiyon kisitlllı̆̆l, ekinovarus.

Tiroid fonksiyon testlerinde tiroid stimülan hormon (TSH) $12 \mu \mathrm{IU} / \mathrm{ml}$ (normal: 0,27-4,2 $\mu \mathrm{IU} / \mathrm{ml}$ ), serbest tiroksin (sT4) 0,78 (normal: 0,93-1,7 ng/dl) sonuçland1 ve hipotiroidi nedeniyle levotiroksin sodyum başland.

Ekokardiyografide perimembranöz ventriküler septal defekt, minimal mitral, triküspit ve aort yetmezliği, patent foramen ovale, hafif hipoplazik asendan aorta ve mezokardi saptand1.

Ultrasonografik incelemede bilateral kalça çıkı ğ 1 saptandı. Babygram incelemesinde fraktür tespit edilmedi. Transfontanel ultrasonografide korpus kallozum agenezisi saptandı. İşitme taraması amaciyla yapılan BERA testinde her iki kulak negatif sonuçlandi.

Kolestaz etiyolojisine yönelik incelemelerinde karaciğer boyutu normal, parankim ekojenitesi hafif heterojen, intrahepatik ve ekstrahepatik safra yolları ve safra kesesi normal saptandi. Alfa 1 antitripsin, alfa fetoprotein, yenidoğan metabolik tarama tetkikleri normal sonuçlandi. Viral serolojik tetkikleri (Hepatit A, B ve C, Toksoplazma, Rubella, Sitomegalovirüs, Epstein Barr Virüs, parvovirus, HIV) negatifti. Artrogripozis, neonatal kolestaz ve renal tübüler asidozu olan hastada ön planda ARC sendromu düşünülerek genetik analiz gönderilmesi planlandi. Ancak ekonomik sorun nedeniyle ilk olarak genetik analiz gönderilemedi ve trombosit morfolojisi ve kanama zamanı normal saptanması üzerine karaciğer biyopsisi yapıldı. Karaciğer biyopsisi sonrası komplikasyon gelişmedi. Karaciğer biyopsisinde fokal safra stazı ve fokal alanlarda hepatositlerde granüler dejenerasyon, portal alanlarda hafif lenfosit infiltrasyonu saptand. İlk günlerde akolik dıșkılaması olan hastanın takibinde dıșkısı kolik hale geldi. Takibinde genetik tanı amaçlı VPS33B geninin yeni nesil dizileme yöntemi ile gerçekleştirilen tüm gen dizi analizi gönderildi.

Kolestazı olan hastaya ursodeoksikolik asit, A, D, E, K vitamin replasmanı başlandı. Anne sütü ile beslenen ancak doğum sonrası tartı alımı olmayan hastanın beslenmesine nazogastrik sonda ile anne sütü ve orta zincirli yağ asitten zengin bir enteral beslenme solüsyonu ile devam edildi. Dirençli metabolik asidozu olmasi nedeniyle oral sodyum bikarbonat tedavisi başlandi. Hastanın yattığı süre boyunca toplamda üç kez sepsis atağ 1 oldu. Taburculuk sonrası takibe gelmeyen hastanın 3 aylıkken evde vefat ettiği öğrenildi. Vefat sonrası genetik 
analiz sonucu belli olan hastanın VPS33B geni 2. ve 3. ekzon bölgeleri dizilenememiş ve bu bölgede delesyon saptanmıştır. Otozomal resesif geçişli bu sendromda aile ağacı çıkarılması planlanmasına karşın vefat sonrası anne ve babadan genetik inceleme gönderilememiş ve bu nedenle sağlıklı bir aile ağacı çıkarılamamıştır.

\section{Tartışma}

ARC sendromu artrogripozis, renal tübüler disfonksiyon ve kolestaz ile karakterize nadir görülen bir hastalıktır. $\mathrm{Bu}$ sendromun en yaygin prezentasyonu neonatal kolestatik sarılıktır. Diğer neonatal kolestatik sarılıktaki klinik tablolardan farklı olarak, hafif yükselmiş veya normal AST, ALT ve düşük veya normal GGT değerleri görülür1. Düşük veya normal GGT ile seyreden kolestaz, ARC sendromunun ayırıcı bir özelliği olarak kabul edilmektedir. Hastamızda kolestaz olmasına rağmen GGT düzeyinin normal olması ve izleminde akolik dışkının düzelmesi; ayırıcı tanıda biliyer atreziden uzaklaşmamıza neden olmuștur. Progresif ailesel intrahepatik kolestaz (PFIC) tip 1 ve 2'de normal serum GGT ile birlikte seyreden kolestaz görülür. $\mathrm{Bu}$ hastalık grubunda (PFICl ve 2) karaciğer biyopsisinde fibrozis, dev hepatositler ve belirgin hepatoselüler kolestaz olur. Hastamızın karaciğer biyopsisinde bu bulguların görülmemesi ve hastamızda artrogripozis ve renal tübüler asidoz (RTA) gibi ekstrahepatik bulguların olması nedeniyle ön planda ARC sendromu düşünülmüştür.

Artrogripozis, ARC sendromunun birincil semptomudur ve kas atrofisi, bileğin radial deviasyonu, her iki kalça ekleminin dislokasyonu, diz eklemlerinin fleksiyon kontraktürü ve kalkaneovalgus dahil olmak üzere çeşitli belirtilerle kendini gösterir3. Ek olarak ARC sendromunda, renal tübüler reabsorbsiyonun bozulmasi ve sekonder hiperparatiroidi ile ilişkili olarak osteopeni ve patolojik kırıklar görülebilir1. Hastamızda belirtilen bulguların çoğu saptanmakla birlikte patolojik kırıklar tespit edilmedi.

$\mathrm{Bu}$ sendromda renal tübüler disfonksiyon, endositoz ve hücre içi trafiğin bozulması ile meydana gelir. Renal tübüler disfonksiyon,
ARC sendromlu hastaların \%100'ünde görülür ve izole renal tübüler asidozdan çoğu vakada olduğu gibi Fanconi sendromuna kadar değişir4,5. S1klıkla RTA, nefrojenik diabetes insipidus, glukozüri, aminoasidüri ve fosfatüri görülür6. Daha nadir görülen renal bulgular, multikistik displastik böbrekler, distal RTA, nefrokalsinozis, interstisyel nefrittir4. Olgumuzda dirençli metabolik asidoz ve elektrolit imbalansina neden olan renal Fanconi Sendromu saptanmıștır. Hastamızda olduğu gibi, RTA yaşamın ilk günlerinde ortaya çıkabilir. ARC sendromlu hastaların \%70'inde küçük böbrekler, nefrokalsinozis ve parankimde hiperekojenite dahil olmak üzere anormal görüntüleme bulgusu vardir4. Hastamızda ise, her iki böbrek boyutları normal olmakla birlikte parankim ekojenitesi grade 1 artmış saptandı.

Hastamızda konjenital kalp hastalığı, korpus kallosum agenezisi, hipotiroidizm, sağırlık ve tekrarlayan sepsis gibi ek özellikler mevcuttu.

ARC sendromunun ek klinik bulguları iktiyoz, anormal trombosit sayı veya fonksiyonu, ikincil enfeksiyonlar ve kardiyovasküler anomalileri içerir. Hastamızda konjenital kalp hastalığ1, korpus kallosum agenezisi, hipotiroidizm, sağırlık ve tekrarlayan sepsis gibi ek özellikler mevcuttu. Aynı aile içinde bile sendroma eşlik eden fenotip değişkenlik gösterebilir, spektrumu oldukça geniştir7.

$\mathrm{Bu}$ sendromda trombosit fonksiyon bozukluğuna bağlı hayatı tehdit eden kanama önemli bir klinik özelliktir. Trombosit fonksiyon anormalliklerinin alfa granül biyosentezinde belirgin azalmaya bağlı olması muhtemeldir8. Trombosit morfolojisi büyük, agranüler ve soluk görünümü ile anormallik gösterebilir9. Vakamızda ise periferik kan yaymasında trombosit morfolojisi normal görülmüş olup kanama zamanı normal saptanmıştır. Organ biyopsisi, ARC sendromundan şüphe edilen bir hastada ciddi kanama riski nedeniyle tehlikeli olabilir. Tanı için mutasyon analizi önerilmektedir1. Ancak hastamızda ekonomik sorun nedeniyle genetik inceleme planlanandan geç ve kisıtlı (VPS33B) gönderilebilmiş ve trombosit morfoloji ve fonksiyonunda bozukluk saptanmamas1 nedeniyle kolestaz ayırıc1 
tanısına yönelik karaciğer biyopsisi yapılmıştır. İşlem sonrası takibinde kanama bulgusuna rastlanmamıştır.

Halihazırda, ARC sendromunun klinik tanısı artrogripozis, RTA ve düşük veya normal GGT ile birlikte neonatal kolestatik sarılık triadı ile patolojik doğrulamanın birlikte tanımlanmasını içerir. Bununla birlikte, hastaların çoğu pihtılaşma defektlerine yatkındır; böbrek veya karaciğer biyopsileri ölümcül kanama riskine sahiptir. Bu nedenle, klinik özellikler ile birlikte VPS33B ve VIPAR sekanslama analizleri, daha güvenli tanısal yöntemlerdir. Ancak mutasyonel analizin, pahalı olması, uzun sürede sonuçlanması ve yanlış negatiflik gibi sinırlamaları vardır. Hastamızda da ekonomik k1sitlamalar nedeniyle ilk olarak VPS33B tüm gen dizi analizi yapılmıştır. Ancak genetik analiz sonucu hasta kaybedildikten sonra belli olmuştur, hastada 2 . ve 3 . ekzon bölgelerinin dizilenemediği ve bu bölgede delesyon olduğu öğrenilmiştir.

ARC sendromu için spesifik bir tedavi mevcut değildir; hastaların yaşam kalitesini artırmak için sıvı infüzyonu, tekrarlayan enfeksiyon tedavileri, ursodeoksikolik asit, yağda çözünen vitaminler, kalsiyum glubionat, levotiroksin ve fosfat gibi destekleyici bakım uygulanır. Bazı hastalarda eklem kontraktürü, konjenital kalça çıkı̆̆ı nedeniyle ortopedik müdahale gerekebilir. Ancak, kötü genel durum ve düşük sağ kalım oranları cerrahinin sonucunu etkileyebileceğinden, agresif ortopedik tedavi hala önerilmemektedir10. Olgumuzun takiplerinde destek tedavileri düzenlendi. Tekrarlayan elektrolit imbalansı ve sepsis atakları hastanın yatış süresinin uzun olmasına neden olmuştur. Hastamıza artrogripozis nedeniyle fizik tedavi uygulanmış, bilateral kalça çıkığı için hedef kiloya ulaştiktan sonra opere edilmesi planlanmıştır.

Multisistemik bir hastalik olan ARC sendromunun prognozu kötüdür. Hastaların çoğu sıvı kaybı, beslenme problemi, kanama ve tekrarlayan enfeksiyonlar nedeniyle yaşamın ilk yılında kaybedilir1. Yoğun replasman tedavilerine rağmen, hastamız yaşamının 3. ayında kaybedilmiştir.

\section{Sonuç}

Sürekli düşük veya normal GGT ile birlikte giden kolestatik sarılık ve kas-iskelet bozukluğu olan hastalarda ARC sendromu akılda tutulmalıdır. Yoğun tedaviye rağmen klinik seyir kötüdür. Bu nedenle aile öyküsü, klasik klinik bulgular ile şüphelenilen hastalarda genetik mutasyon analizi ve/veya karaciğer veya böbrek biyopsisi ile erken evrede tanı konulması, ailenin sonraki çocukları için genetik danışmanlık alması açısından önemlidir. Moleküler genetik ve tıbbi teknolojilerin ilerlemesiyle gelecek gen terapisi girişimleri, ARC sendromunu daha iyi yönetebilmeyi hatta iyileştirmeyi sağlayabilir.

\section{KAYNAKLAR}

1. Zhou Y, Zhang J. Arthropryposis-renal dysfunction-cholestasis (ARC) Syndrome: From Molecular Genetics To Clinical Features. Ital J Pediatr. 2014;40:77.

2. Aflatounian M, Smith H, Farahani $F$ et al. Novel VIPAS39 Mutation In A Syndromic Patient With Arthrogryposis, Renal Tubular Dysfunction And Intrahepatic Cholestasis. Eur J Med Genet. 2016;59:237-9.

3. Taha D, Khider A, Cullinane AR et al. A Novel VPS33B Mutation In An ARC Syndrome Patient Presenting With Osteopenia And Fractures At Birth. Am J Med Genet A. 2007;143A:2835-2837.

4. Duong MD, Rose CM, Reidy KJ et al. An Uncommon Case Of Arthrogryposis, renal

dysfunction, and cholestasis (ARC) Syndrome And Review Of The Renal Involvement: Answers. Pediatr Nephrol. 2020;35:249-251.

5. Arhan E, Yusufoğlu AM, Sayli TR. ARC Syndrome Without Arthrogryposis, With Hip Dislocation And Renal Glomerulocystic Appearance: A Case Report. Eur $J$ Pediatr. 2009;168:995-8.

6. Malaki M, Mandana R, Ghaffari S. ARC Syndrome With Complex Renal Problems: Nephrocalcinosis, Proximal And Hyperkalemic Distal RTA And Nephrogenic Diabetes Insipidus. Saudi J Kidney Dis Transpl 2012, 23:804-9.

7. Cullinane AR, Straatman-Iwanowska A, Seo JK et al. Molecular Investigations To Improve 
Diagnostic Accuracy In Patients With ARC Syndrome. Hum Mutat. 2009;30:E330-E337.

8. Mutlu M, Aslan Y, Aktürk-Acar $\mathrm{F}$ et al. ARC syndrome. Turk J Pediatr. 2017;59:487-90.

9. Saadah OI, Bokhari BE, Alshaeri TM et al. Haematological Manifestations Of Arthrogryposis-renal dysfunction-cholestasis (ARC) Syndrome: A Case Report. Arab J Gastroenterol. 2013;14:26-28.

10. Jang WY, Cho TJ, Bae JY et al. Orthopaedic Manifestations of Arthrogryposis-renal dysfunction-cholestasis Syndrome. $J$ Pediatr Orthop. 2011;31:107-12.

๑Copyright 2020 by Osmangazi Tıp Dergisi - Available online at tip.ogu.edu.tr @Telif Hakkı 2020 ESOGÜ Tıp Fakültesi - Makale metnine dergipark.org.tr/otd web sayfasından ulaşılabilir. 